\title{
INTRODUCTION
}

This book investigates stories of growing old from Petrarch's to Montaigne's time. My concerns with this project are twofold. First, I explore a shift in attitudes towards aging. From the late fourteenth to the end of the sixteenth centuries, the elderly subject became a focus of new social, medical, political, and literary attention on both sides of the Alps. A movement of secularization-inspired by the revival of classical literature-tended to dissociate old age from the Christian preparation for death, and downplayed the role of the afterlife, re-orienting the concept of aging around pragmatic matters such health care, intergenerational relationships, and insights one might acquire in later life and pass along. Such changes were accompanied by an increasing number of personal accounts of later life expressed from a variety of perspectives, and in multiple ways. As old age became the subject of intense personal reflection and widespread public debate, new literary forms of elder identity appeared, which drew upon previous texts, combined several sources, subverted them, and departed from them. Stories of growing old became more differentiated and complex, yet these self-portraits were less the faithful records of lived experiences than rhetorical constructions that took their full meaning in a society and culture increasingly interested in questions related to longevity.

My second goal is to provide a historical perspective on a crucial problem of our time. The United Nations foresees an unprecedented global demographic transformation in the near future: by 2050, people aged sixty and beyond will outnumber those under fifteen. Currently, the fastest growing segment of the Western World is those aged eighty-five and beyond. Looking back to the fifteenth and sixteenth centuries, the few demographical statistics indicate that life expectancy at birth averaged around thirty-five years in parts of Italy and France. However, historians have noticed an extension of the life span during this period, partly the result of a decrease in birth mortality rates. ${ }^{1}$ Nevertheless, people did grow old in the Renaissance, and in larger numbers than is often thought,

${ }^{1}$ See Christiane Klapisch and D. Herlihy, Les Toscans et leur famille: une étude du catasto florentin de 1427 (Paris: Ecole des Hautes Etudes et Fondation nationale des Sciences Politiques, 1978); Arlette Higounet-Nadal, Périgueux aux XIV et XVe siècles. Etude de démographie historique (Bordeaux: Fédération historique du Sud-Ouest, 1977), pp. 805-15. See also Georges Minois, Histoire de la vieillesse en Occident de l'Antiquité à la Renaissance (Paris: Fayard, 1987), pp. 287-337. 
although the definition of old age varied from place to place and according to one's point of view, as we shall see. My working assumption is that common denominators across centuries are as revealing as significant differences: my aim is to consider how accounts from a distant period help us to see what might be universal in the ways Western culture deals with an irreversible biological phenomenon. Shifting the focus from a particular time period to a broader context allows a series of concerns to come to the fore. Throughout the centuries, aging people have had similar aspirations and anxieties about human life: coping with changes in their cognitive and physical capacities; keeping the affection of relatives and the esteem of their social group; remaining active in their communities. On the one hand, my findings convinced me that one learns more about how to respond to these challenges by reading Petrarch, Montaigne and their classical sources than contemporary self-help books. On the other hand, my reading of Renaissance stories of later life pointed out that personal experiences are embedded in the systems of knowledge (cultural, social, medical, and so on) of the day.

The texts that are investigated offer forms of resistance to the view of aging as a process of straightforward physical and cognitive decay, and it is this perspective more than anything that allows me to bring together materials that are usually kept separate. The notion of old age is not challenged, but there is a refusal to see it as totally negative and unproblematic, and an attempt to focus on the quality of the elder's lifestyle as well as on the meaning of his later years. I do not offer a narrow definition of the notion of "aging gracefully," since its meaning depends not only on an individual's personal values and priorities, but also on those of the cultural and historical context in which this individual lives. Rather, the various chapters of this study provide an array of perspectives on how to age gracefully. In its broadest application, my work will enhance our own perceptions of aging gracefully by revisiting the formative writing on this issue in Renaissance stories of later life. This book will, I hope, build a bridge between the cultures of Petrarch's and Montaigne's time, and the twenty-first century. It is this anthropological perspective that inspired my project. Moving from the view that growing old is something that "happens" to people, I study it as a process with which individuals have to engage and which requires a variety of skills - self-understanding, observation, adaptation, imagination, and humor-to compensate for losses and perhaps turn them into opportunities. As such, this work will be of interest to historians, literary scholars, students, sociologists, and social gerontologists alike. 
Petrarch and Montaigne, and the centuries that separate them are at the heart of my study. Both authors' works epitomize a turn inward towards a psychological and philosophical investigation of human identity-towards what we now call "the self." Scholars have long seen in this turn the mark of Petrarch's and Montaigne's modernity; yet ever since the publication of Jacob Burckhardt's influential book, The Civilization of the Renaissance in Italy (186o), ${ }^{2}$ critics have focused on creating a static conception of identity from Petrarch onward, without taking into account the "aging factor." Petrarch claimed to have "gray hair considerably before [his] twenty-fifth year;"3 his self-portraits in works as different as his Letters on Familiar Matters, his Letters of Old Age, his Secretum, and his Rime Sparse (or Rerum Vulgarium Fragmenta as he used to call this collection) refer to a writer growing old. Likewise, Montaigne's obsession with time has attracted much comment, but his pervasive references to himself as an old man have not been fully appreciated. At age forty (seven years before the first edition of his Essais in 1580), he considered himself "engagé dans les avenuës de la vieillesse" ("well on the road to old age" (II, 17, p. 641/p. 590)). ${ }^{4}$ He found ways to confront death, but growing old proved a more challenging and pressing task. For both authors, the process of aging was a mode of thought that opened up new ways to relate to oneself, to the other, and the world. Their respective experiences drew their attention to questions of literary self-perception, and contradicted the prevailing view that old age is a distinct stage of life, with common and homogeneous characteristics. The eroding of an "ages of life" culture and the awakening to the instability of individual identity across time carried with it the potential for increased self-understanding, as we shall see.

Petrarch's self-portraits in old age have religious and moral overtones; in the Letters of Old Age especially, they blend Christian and pagan perspectives to present the author as a Christianized Ancient. About

2 Jacob Burckhardt, The Civilization of the Renaissance in Italy, trans. S. C. C. Middlemore, introd. B. Nelson and C. Trinkaus (New York: Harper, 1958). See also Stephen Greenblatt, Renaissance Self-Fashioning. From More to Shakespeare (Chicago: Chicago University Press, 1980).

3 "canos aliquot ante vigesimum quintum annum habui..." Le Familiari, ed. V. Rossi (Florence: Sansoni, 1934), VI, 3, vol. 2, p. 67. All Latin references are taken from this edition. Letters on Familiar Matters (Rerum Familiarium Libri), trans. and ed. Aldo Bernardo (Albany, New York: State University of New York Press, 1975), VI, 3, vol. 1, p. 303. All English translations refer to this edition and are incorporated into the text.

4 Page numbers for Montaigne's Essais refer first to the standard edition, edited by Pierre Villey and Verdun-L. Saulnier (Paris: PUF, 2004), and then to Donald Frame's translation The Complete Works of Montaigne (New York: Knopf, 2003). 
two hundred years later, Montaigne's Essais offered another powerful self-representation. In contrast to the relative cohesion of Petrarch's various self-portraits in old age, Montaigne offered a polyphonic and mobile image of his aging self, marked by discontinuities, and contradictions. Like Petrarch, Montaigne pointed to early signs of old age. From his thirties on, he was certain that "since that age, [his] mind and [his] body ha[d] rather shrunk than grown, and gone backward rather than forward" (I, 57, p. 327/p. 289). Such comments need a closer look, as we shall see.

My analyses are indebted to previous scholarship on Petrarch, Montaigne, and the Renaissance. Stephen Greenblatt's study on Renaissance Self-Fashioning has been inspirational insofar as it focuses on an individual's power to shape his own image, and investigates how representations are embedded in different structures of power specific to a certain community. Greenblatt, however, does not examine the importance of elders' self-portraits in the formation of early modern subjectivity. Works on Montaigne by Hugo Friedrich, Jean Starobinski, and Craig Brush have also been useful. Victoria Kirkham and Armando Maggi's edited collection of essays on Petrarch have been likewise very helpful..$^{5}$ In contrast to these critics, I have attempted to provide a historically specific sense of personal stories of old age by reading them in the intellectual and social context out of which they arose. Petrarch's and Montaigne's self-portraits in their later life, I contend, responded to contemporary arguments on age, and either endorsed, questioned, repudiated, or ignored prevailing assumptions on this issue. My views on aging have benefited from works by Helen Small, Sulamit Shahar, Nina Taunton, Pat Thane, and Kathleen Woodward, among others. ${ }^{6}$ In addition, in their recent editions of essays, Erin Campbell, Albrecht Classen, Colette Winn and Cathy Yandell have

5 Greenblatt, Renaissance Self-Fashioning; Hugo Friedrich, Montaigne, trans. D. Eng, (Berkeley: University of California Press, 1991); Jean Starobinski, Montaigne en mouvement (Paris: Gallimard, 1983); Craig B. Brush, "What Montaigne has to say about old age," in $O$ un amy! Essays on Montaigne in Honor of Donald M. Frame, ed. Raymond C. La Charité (Lexington, Ky: French Forum, 1977), pp. 89-118; Victoria Kirkham and Armando Maggi, eds., Petrarch: A Critical Guide to the Complete Works (Chicago: University of Chicago Press, 2009).

6 Helen Small, The Long Life (Oxford: Oxford University Press, 2007); Sulamit Shahar, Growing Old in the Middle Ages. "Winter Clothes Us in Shadow and Pain," trans. Yael Lotan (London, Routledge, 1997); Nina Taunton, Fictions of Old Age in Early Modern Literature and Culture (New York: Routledge, 2007); Pat Thane, The Long History of Old Age (London: Thames and Hudson, 2005); Kathleen Woodward, At Last, the Real Distinguished Thing: The Late Poems of Eliot, Pound, Stevens, and Williams (Columbus, Ohio: Ohio State University Press, 1980). 
added a great deal of information on old age in the Renaissance. ${ }^{7}$ Georges Minois's History of Old Age from Antiquity to the Renaissance has also fed my reflections, ${ }^{8}$ although my study challenges his contention that the Renaissance epitomized a cult of youth and a general criticism-even hatred - of the elderly. At every given historical moment, indeed, concurrent perspectives on age circulate within a specific social group. By taking into account this diversity, a more richly textured history emerges that makes clearer differences among individuals, social and political groups, as well as times and places.

In contrast to these previous works on old age in the Renaissance, the theoretical approach for this project takes as a point of departure Michel Foucault's research on the "care of the self" as weaving together individuality and collectivity. Foucault never spoke of old age, yet his research has provided apt tools for sociological discussions on the construction of gerontology as a discipline, and on postmodern views on aging identity. ${ }^{9}$ In "The Subject and Power," he offered a retrospective account of his intellectual undertakings: "My objective [...] has been to create a history of the different modes by which, in our culture, human beings are made subjects." ${ }^{10}$ His focus on the constitution of the self as a subject of desire in his History of Sexuality (especially in the second volume, The Use of Pleasure) is only one of the historical forms in which the subject "was problematized, becoming an object of concern, an element for reflection, and a material for stylization." 11 Drawing on a number of strands, including

7 Erin Campbell, ed., Growing Old in Early Modern Europe. Cultural Representations (Burlington, Vt: Ashgate, 2006); Albrecht Classen, ed., Old Age in the Middle Ages and the Renaissance: Interdisciplinary Approaches to a Neglected Topic (New York: De Gruyter, 2007); C. Winn and Y. Yandell, eds., Vieillir à la Renaissance (Paris: Champion, 2009).

8 Georges Minois, Histoire de la vieillesse en Occident de l'Antiquité à la Renaissance, pp. $287-337$.

9 See Stephen Katz, Disciplining Old Age. The Formation of Gerontological Knowledge (Charlotte: University of Virginia Press, 1996), especially pp. 6-24; Jason Powell and Azrini Wahidin, ed., Foucault and Aging (Hauppauge, NY: Nova Science Publishers, 2006).

10 Michel Foucault, "The Subject and Power," in Michel Foucault Beyond Structuralism and Hermeneutics, ed. H. L Dreyfus and P. Rabinow (Chicago: Chicago University Press, 1983), pp. 208-9. See also "The Ethic of Care for the Self as a Practice of Freedom. An Interview with Michel Foucault on January 20, 1984," in The Final Foucault, ed. James Bernauer and David Rasmussen (Cambridge, Mass.: MIT Press, 1988), p. 10: "What I wanted to know was how the subject constituted himself, in such and such a determined form, as a mad subject or as a normal subject, through a certain number of practices which were games of truth, applications of power, etc."

11 Michel Foucault, The History of Sexuality vol. 2, The Use of Pleasure, trans. R. Hurley (New York: Pantheon Books, 1986), pp. 23-24. 
Pierre Hadot's research on spiritual exercises in the culture of Antiquity, ${ }^{12}$ Foucault's later works studied "an aesthetic of existence" where the individual seeks to shape his life through conscious self-fashioning. In his lectures on L'Herméneutique du sujet at the Collège de France, he highlighted a new consciousness of the "relation of oneself to oneself" ("rapports de soi à soi") dominated by the idea of "care for oneself" ("souci de soi") in texts mostly from the Hellenistic period. This involved not only a general attitude, but also working on the self through a number of practices ("technologies de soi"). ${ }^{13}$ Foucault envisioned the care of the self in a triple perspective, as 1) a general way of considering things, a way of being; 2) a form of attention to oneself; 3) a number of practices that an individual performs on himself which shape his behavior and mode of being. The common objective of these "pratiques de soi" is a conversion to oneself, which involves a shift of perspective, and "a trajectory thanks to which, escaping all dependency and enslavement, we return to ourselves, as to a harbor sheltered from storms."14 L'Herméneutique du sujet discusses practices ranging from health regimens to the Delphic imperative of knowing oneself in Platonic dialogues, and to Stoic and Epicurean conceptions of human life.

Foucault argued that the turn to the self-and to self-knowledge-has meant different things under different regimes of self-formation. His studies on the constitution of different forms of the subject in specific time periods show how some fields of knowledge have constrained human freedom and attempt to provide the intellectual resources for overcoming current constraints by replacing them in a historical perspective. His work has provided analytical paradigms of wider applicability, and my inquiry is yet another confirmation of the vitality of his legacy. In fact, I might apply to my use of his historical framework what Foucault himself rather teasingly said of Nietzsche:

The only valid tribute to thought such as Nietzsche's is precisely to use it, to deform it, to make it groan and protest. And if commentators then say

12 Pierre Hadot, Exercices spirituels et philosophie antique (Paris: Etudes augustiniennes, 1981). See also P. Hadot, Philosophy as a Way of Life, ed. A. I. Davidson, trans. M. Chase (Chicago: Chicago University Press, 1995).

13 Michel Foucault, L'Herméneutique du sujet. Cours au Collège de France 1981-1982, ed. F. Ewald, A. Fontana, F. Gros (Paris: Gallimard, 2001), pp. 12-13.

${ }_{14}$ Michel Foucault, The History of Sexuality, vol. 3, The Care of the Self, trans. R. Hurley (New York: Vintage Book, 1986), p. 57. 
that I am being faithful or unfaithful to Nietzsche that is of absolutely no interest. ${ }^{15}$

My study elaborates on Foucault's project of "a history of the different ways in our culture that humans develop knowledge about themselves,"16 in a new direction and another time period. Each chapter examines stories of growing old along Foucault's major axes of research-medicine, power, love, and most importantly, the body-in a different sphere: private life, the public realm of political affairs, the social world of the court and salons. ${ }^{17}$

Chapter 1, "A Sound Mind in a Healthy Body," examines the creation of a market for health regimens among wealthy seniors. The old man became an object of medical observation; his daily health care was a matter of private preoccupation, as shown in texts by Petrarch, Ficino, Zerbi, Erasmus, Cornaro, and Montaigne. Chapter 2 discusses the "Circulation of Power and Knowledge" among generations, given that a large number of male elders held high positions in the public sphere. Amidst political turmoil, the reactions of Petrarch, Castiglione, and Montaigne to Cicero's defense of gerontocracy in De Senectute offered ways to restore social peace and harmony through dialogue between youth and old age. Chapter 3, "Love in Old Age," is about aged writers who acknowledged themselves as subject to desire and sought new ways to articulate the stereotypes of both the chaste and the lustful old man, as well as the traditional opposition of old versus young. Petrarch addressed these questions within a Christian framework; with the graying of the courts and salons of the sixteenth century, however, the posture of the aged lover led Ronsard, Montaigne, and Pasquier to raise issues concerning social behavior. Finally, chapter 4, "Then and Now," addresses the connection between these newly conceptualized representations of old age and the notion of aging gracefully in the present time; it also discusses self-portraits of later life- especially Montaigne's-in terms of discursive tactics. Although the assumptions underlying Renaissance self-representations of later life differ from those of the twenty-first century, their investigation into aging as

15 M. Foucault, "Prison Talk," in Power/Knowledge. Selected Interviews and Other Writings, 1972-1977, ed. C. Gordon (Brighton: Harvester, 1981), pp. 53-54.

16 L. H. Martin, H. Gutman, and P. H. Hutton, eds., Technologies of the Self: A Seminar with Michel Foucault (Amherst, MA: University of Massachussetts Press, 1988), pp. 17-18.

17 See especially Michel Foucault, Surveiller et punir. Naissance de la prison (Paris: Gallimard, 1975); Histoire de la folie à l'âge classique (Paris: Gallimard, 1961); Histoire de la sexualité, vol. 1 (Paris: Gallimard, 1976); Naissance de la clinique. Une archéologie du regard médical (Paris: PUF, 1963). 
a process of self-understanding and an attempt to adapt to human finitude still speaks to us.

This work is not the story of a progressive refinement of selfrepresentations from Petrarch's to Montaigne's time; indeed, there is no single history of old age. All these authors, nevertheless, referred to the same biblical, medical, and literary sources, as well as to a common set of literary conventions, and stereotypes of age. The four chapters are relatively independent studies and do not constitute a progressive story, although they move from questions concerning an individual's cognitive and physical capacities to issues regarding his relationships with others. Moreover, their lines of inquiry have in common issues of adaptation and self-knowledge.

By reconfiguring our conception of aging through Foucault's notion of "care of the self" as a practice of both the individual and the collective, my work capitalizes on Foucault's invitation to further exchange on this matter, and contributes to ongoing conversations between the humanities, the sciences, and the social sciences on aging.

The remainder of this introduction discusses the notion of old age and defines my field of inquiry.

\section{Old Age}

Any attempt to address the issue of aging must acknowledge that this discourse involves multiple perspectives-biological, chronological, social, psychological, functional, cultural, and so on. In addition, each individual has a subjective estimate of his own condition, which may not correspond to the way he looks in the eyes of others. No unified view can take into account all these levels. There is no overarching definition of old age. Moreover, if death marks the end of old age, how do we identify the beginning of this phase? In the schemes for the division of life into stages elaborated from classical Antiquity through the sixteenth century (the number of these stages varied from three to seven, and could even go up to twelve), ${ }^{18}$ several ages were suggested as the onset of old age: thirty-five, forty-five, fifty, sixty, seventy. These schemes referred to specific contexts (religious, medical, scientific, literary, among others) and to

18 See Samuel Chew, The Pilgrimage of Life (New Haven: Yale University Press, 1962), pp. 148-73; Elizabeth Sears, The Ages of Man. Medieval Interpretations of the Life Cycle (Princeton: Princeton University Press, 1986). 
different social groups; as such, they related to different conceptions of human nature and of time.

The earliest representations of the course of life as a rising and declining stairway appeared between the end of the fifteenth century and the middle of the next century. The image was so evocative that it quickly spread in German, French, and English prints; Paris became an important center for its production in the sixteenth century. ${ }^{19}$ In a late fifteenthcentury German print, for instance, we see a staircase with a cradle at ground level; ascending the stairs appear in succession a child, an adolescent, and a young man. On the landing there is a middle-aged man. On the right the man goes down gradually as he grows older, and reaches a deathbed, then a tomb. One of the paradoxes of these representations is their acknowledgment that human beings are aging from the moment of their birth, but at a certain point in life they are identified as "old." Chronological age explains nothing; it is only an arbitrary index. Nor is aging a homogeneous and even process; each of us ages in a particular way; moreover, we all grow old "by pieces" insofar as the various parts of our body and mind age at different rates.

The aging family of words can be understood as a concept only in the sense in which Ludwig Wittgenstein used the term "concept," that is, as a rope composed of numerous interwoven fibres that are neither identical nor unrelated to each other: "the strength of the thread does not reside in the fact that some one fibre runs through its whole length, but in the overlapping of many fibres." ${ }^{20}$ For Wittgenstein, the meaning of a concept lies in its uses. ${ }^{21}$ Since "old age" embraces a great diversity of capacity and experience, writers such as Petrarch and Montaigne selected certain aspects from its wide range of meanings to instigate precise actions, to discuss some practices, to judge some behaviors, provoke feelings, and question various beliefs. Old age lends itself well to debates because it often involves evaluation, celebration or denigration, but rarely indifference. In every period, it has been praised and cursed, honored and resented. In the Renaissance, arguments in praise of and against it were gathered from the Greeks and Romans, the Bible, the Church fathers, as well as medieval writers. The extreme texts bore the imprint of remarkably

19 David Troyansky, Old Age in the Old Regime. Image and Experience in 18th-Century France (Cornell: Cornell University Press, 1989), p. 12.

20 Ludwig Wittengstein, Philosophical Investigations (Oxford: Oxford University Press, 1968), p. 32.

21 Ibid., p. 20. 
stable — negative or positive — stereotypes of age. Aristotle's Rhetoric and Nicomachean Ethics disseminated negative stereotypes by describing the old man as selfish, mean, bitter, cowardly unreliable, suspicious, and socially dysfunctional. For Aristotle, the old man idealizes his past and blames the present; his alleged experience is the sum of the mistakes he made in the course of his long life. ${ }^{22}$ Plato's Republic and Cicero's Cato Maior De Senectute, on the other hand, celebrated old age, stressing the elder's wisdom, serenity, and perceptive judgment. ${ }^{23}$ This fundamental dialectic, which has long roots in Egyptian, Jewish, and Babylonian traditions, ${ }^{24}$ shows the relational nature of age stereotypes: the qualities attributed to old age are in fact the shortcomings attributed to youth, and vice-versa. The figures on whom this study focuses questioned the nature of these binary views, as we shall see.

So far, I have left aside an obvious question: how visible were the elders in Petrarch's and Montaigne's societies? How old were they? According to Petrarch, longevity had become a banal aspect of everyday life:

Plato lived to be eighty-one; and it is said to have been considered such a phenomenon that, because he had completed the most perfect age, it was acknowledged that the Magi offered sacrifices to him as though he were more than a man, whereas today in our cities we see this kind of longevity all around; octogenarians, and nonagenarians are common...(Sen. XVII, 2, p. 651$)^{25}$

22 Aristotle, On Rhetoric. A Theory of Civic Discourse, ed. and trans. G. Kennedy (Oxford: Oxford University Press, 2007), II, 13, 1389b-90a; Nicomachean Ethics, ed. and trans. E. D. Ross (Oxford: Oxford University Press, 1980), IV, 3, 1121; VIII, 7.

23 Plato, The Republic, ed. and trans. R. Allen (New Haven: Yale University Press, 2006) I, 1328a-1330c, p. 76; Cicero, De Senectute, De Amicitia, De Divinatione, ed. and trans. W. A. Falconer (London: Heinemann, 1923). On Cicero's De Senectute, see chapter 2.

24 See Jan Baars, "Philosophy of Aging, Time, and Finitude," in A Guide to Humanistic Studies in Aging. What Does It Mean To Grow Old?, ed. Thomas R. Cole, R. E. Ray, and R. Kastenbaum, (Baltimore: Johns Hopkins University Press, 2010), pp. 107-8; and Stephen Sapp, "Aging in World Religions. An Overview," in Cole, Ray, and Kastenbaum, A Guide to Humanistic Studies in Aging, pp. 129-33.

25 Petrarch, Letters of Old Age (Rerum Senilium Libri), trans. and ed. A. S. Bernardo, S. Levin, and R. Bernardo (Baltimore: Johns Hopkins University Press, 1992), vol. 2, book XVIII, letter 2, p. 651. All further references are taken from this edition (abridged mention: Sen.) and incorporated into the text. The first-Roman-number refers to the book number, the second one to the letter number. When needed, I have added a reference to the Latin text taken from Les Lettres de la vieillesse, 4 vols., ed. E. Nota et al. (Paris: Les Belles Lettres, 2002-6), (abridged mention: Lettres). Nota's edition is far superior to the previous ones. Vol. 5 appeared too late for me to consult it. For the Latin text of the last books of the Seniles, I have therefore consulted F. Petrarca, Le "Senili" secondo l'edizione Basilea 1581, ed. Marziano Guglielminetti, M. Martelli, and P. Pellizzari (Torino: L’Artistica Editrice, 2004). 
Petrarch knew that Cato, Varro, and other Ancients had become centenarians, but found the frequency of contemporary cases of old age striking. His own paternal great-grandfather passed away in "the one hundred and fourth year of life," he wrote to Giovanni Colonna (Fam. vol. 1, VI, 3, p. 302$).{ }^{26}$ In addition, he mentioned a famous hermit, Romuald of Ravenna, who "recently lived a hundred and twenty years" (Sen. XVII, 2, p. 651). About two centuries after Petrarch's observations, Girolamo Cardano recalled his conversations with a tailor from Padua who claimed to be a centenarian, and with a Milanese baker and a man from Pavia who both said they were ninety-six years old. Cardano, who boasted about his ability to judge age accurately, thought that the man from Pavia was only ninety years old because he was not as thin as the other two, and his eyelids were not that deeply sunken. All three men were healthy, but the native of Padua suffered from constipation and memory losses. Cardano concluded that in contemporary Italy one could live up to one hundred years, but that only octogenarians had their mental and physical faculties relatively intact. ${ }^{27}$ Some information Petrarch and Cardano got hold of was clearly flawed. Moreover, people who were vague about their chronological age gave themselves an arbitrary birth date to show that they were old. In everyday life, old age was primarily a matter of physiological marks and capacities, hence a man could be identified as "old" at variable ages.

On the other hand, Montaigne thought that dying of old age was "a rare death, unique and out of the normal order." At age forty-seven, he considered being at an age "few people reach" and thought he had "passed the customary limits which are the true measure of our life" (I, 57, p. 326/p. 288). He was closer to the truth than were Petrarch or Cardano. Yet as soon as one starts thinking in terms of longevity, a host of famous French and Italian writers who lived beyond age sixty comes to mind: Petrarch (1304-1374), Leone Battista Alberti (1404-1472), Girolamo Cardano (1501-1576), Blaise de Monluc (ca. 1502-1577), Etienne Pasquier (1529-1615), Simon Goulart (1548-1628), Philippe Duplessis-Mornay (15491623), Agrippa d'Aubigné (1552-1630), and more. Philip Sohm has made a similar observation in the visual arts: from 1500 to 1700 , two-thirds of

\footnotetext{
26 "quarto ac centesimo etatis anno," Familiari, vol. 2, p. 66. On Petrarch's greatgrandfather, see chapter 1 , the section on Petrarch.

27 Girolamo Cardano, Opera 6: 57, quoted by Nancy Siraisi, The Clock and the Mirror. Girolamo Cardano and Renaissance medicine (Princeton: University Press, 1997), p. 40.
} 
the 975 Italian painters with a known date of birth were sexagenarians or beyond by the time of their death. ${ }^{28}$

When it came to life expectancy, the gap between the rich and the poor was obvious. Interestingly, Francis Bacon (1561-1626), who was deeply concerned with issues of longevity, observed that seventeenth-century members of the Church of England (high-ranked ecclesiastics, monks, and nuns from prosperous abbeys and convents) and people from the professions with a comfortable income and a high level of education had the best chance of living long lives. ${ }^{29}$

\section{Scope of This Inquiry}

Clearly, old age's multiple forms of expression and representation are a major part of a cultural and intellectual investigation of the Renaissance. Yet an exhaustive analysis of this question is unrealistic since it is impossible to reconstruct the context of a distant period in its entirety. This problem is particularly acute in the present case since the notion of old age "functions" without a sharp distinction between literature and other disciplines. My inquiry crosses the boundaries between medicine, ethics, and the construction of literary characters; it concerns private and public matters; it involves examining social modes of behavior and reflections on the cultural codes that partly shape these behaviors. Analyses of old age also must take into account gender, class, historical and personal circumstances.

Given the scope of these issues, I should emphasize what this book does not discuss. Hence my study is as important for what it leaves out as for what it includes, and, ultimately, for the interest it may provoke in others to broaden this inquiry. I have not addressed the female experience of aging, which differed from that of the male experience and had its own set of issues. From Antiquity to the Renaissance, men wrote health regimens and medical treatises for a male audience, although most advice applied to women as well. Moreover, questions related to age in political affairs usually referred to male elders; other problems such as intergenerational

28 Philip Sohm, The Artist Grows Old. The Aging of Art and Artists in Italy, 1500-180o (New Haven: Yale University Press, 2007), p. 15.

29 Francis Bacon. The Instauratio Magna, vol. 3, Historia naturalis et experimentalis. Historia ventorum. Historia vitae et mortis, ed. G. Rees (Oxford: Clarendon Press, 2007), chapter 20. 
conflicts and social behaviors in old age are also gender-specific. I have not included problems related to the poor and the creation of asylums for the elderly. In turning to literature I have not included plays. Although they often portray old men, they do not provide much insight on personal stories of later life. I have not addressed questions related to "fountains of youth," occult means of rejuvenation, and attempts to live forever, which lie outside my investigation. Finally, I do not include representations of death since my study focuses on the dissociation of old age from such views.

Instead, I have examined poems, letters, and prose texts by major Italian and French writers who grew old in the upper social classes and the cultural elite of their time. These are stories that go in different directions, depending on the point of view from which they are told, the context, the date, the implied audience, and so on. My study takes up samples of such representations. Petrarch and Montaigne are present throughout the four chapters because their self-portraits provide us with the most complex and thorough perspectives on the aging self. Some authors appear only episodically, depending on the nature and impact of their views. The medical treatises of Zerbi and Ficino are part of the discussion on the care of the aging self, as is Cornaro's powerful text on health at old age (chapter 1). Erasmus's ironic paradoxes on old age in Praise of Folly and his religious perspectives on health in later life appear in the same chapter. Castiglione's Libro del Cortegiano appears in chapter 2 since it raises important concerns on the social and political implications of old age. Ronsard and Pasquier are part of the chapter on love in old age (chapter 3).

There is a network of connections among these writers. Montaigne knew Petrarch's works, including his correspondence; he had read Ficino, Erasmus, Castiglione, Ronsard, and perhaps Cornaro. Moreover, he was a friend of Pasquier, who admired his Essais. The love verses of Pasquier and Ronsard bore the imprint of Petrarch's Rerum Vulgarium Fragmenta.

We will now turn to how these writers capitalized on a common literary and scientific tradition, as well as on the various constraints that weighed upon them as they fashioned themselves in the winter of life. 